\title{
Assessment of Heavy Metal Attenuation and Mobility in Compacted Soil Columns
}

(Penilaian Pembantutan dan Kemobilan Logam Berat dalam Turus Tanah Terpadat)

\author{
WAN ZUHAIRI, W.Y.* \& NURITA, R.
}

\section{ABSTRACT}

Groundwater pollution from unlined landfill is a worrying problem nowadays. In order to reduce the pollution, a good soil liner is very important. Natural compacted soil is used to prevent leachate from reaching the groundwater. The soil column study was performed to investigate the retention capability of three soil types in Malaysia, namely marine clay $(S B M C)$, weathered metasediments (HMS) and river alluvium soil (ARA). All soil columns were tested against four types of heavy metals, i.e. lead (Pb), copper (Cu), nickel (Ni) and zinc (Zn). The breakthrough curves show that the SBMC has better retention capability on heavy metals compared to other soils; indicating less migration of heavy metals through SBMC soil column. The affinity of heavy metals for adsorption were also varied with soil types and can be ranked as follow: $S B M C(P b>C u>N i \approx Z n)$ and HMS/ARA: $Z n \approx C u>P b>N$. Soil SBMC showed very high resistance to acidic test solution (i.e. high buffering capacity), where the $\mathrm{pH}$ values throughout the test were in an alkaline region with the values of $\mathrm{pH} 8$ to 7. The study also discovered that heavy metals entered the soil columns were retained predominantly at the top $30 \mathrm{~mm}$. Engineering applications of these findings show that soil SBMC has a very good potential to function as soil liner material compared to two other soils (ARA and HMS).

Keywords: Breakthrough curves; column experiment; heavy metals; retention profile; soil liner

\section{ABSTRAK}

Pencemaran air bawah tanah dari tapak pelupusan sisa tidak berlapik adalah suatu masalah yang membimbangkan pada masa kini. Untuk mengurangkan pencemaran, pelapik tanah yang baik sangat penting. Tanah semula jadi yang dipadatkan digunakan untuk mencegah cecair larut resapan daripada mencemari air bawah tanah. Kajian turus tanah dilakukan untuk mengkaji keupayaan penahanan tiga jenis tanah di Malaysia, iaitu lempung marin (SBMC), tanah metasedimen (HMS) dan tanah aluvium sungai (ARA). Kesemua tanah diuji terhadap empat jenis logam berat, iaitu plumbum (Pb), kuprum (Cu), nikel (Ni) dan zink (Zn). Graflengkung penembusan menunjukkan bahawa tanah SBMC mempunyai keupayaan penahanan logam berat yang lebih baik berbanding dengan tanah lain. Ini menunjukkan logam berat kurang mengalami migrasi melalui ruang tanah SBMC. Pemilihan logam berat untuk penjerapan juga berbeza-beza dengan jenis tanah dan boleh disenaraikan seperti berikut: $S B M C(P b>C u>N i \approx Z n)$ dan HMS/ARA: $\mathrm{Zn} \approx \mathrm{Cu}>\mathrm{Pb}>\mathrm{Ni}$. Tanah SBMC menunjukkan rintangan yang sangat tinggi terhadap larutan berasid (iaitu kapasiti penampan tinggi), dengan nilai pH sepanjang ujian berada dalam keadaan alkali antara pH 8 hingga 7. Kajian ini juga mendapati bahawa logam berat yang memasuki liang tanah mengalami penahanan terutamanya pada bahagian $30 \mathrm{~mm}$ teratas. Aplikasi kejuruteraan penemuan ini menunjukkan bahawa tanah SBMC mempunyai potensi yang sangat baik untuk berfungsi sebagai bahan pelapik tanah dibandingkan dengan dua tanah lain (ARA dan HMS).

Kata kunci: Lengkung penembusan; logam berat; pelapik tanah; profil penahanan; ujian turus

\section{INTRODUCTION}

Soil has been regarded as the cheapest material that can be used as compacted clay liner in waste disposal landfills to prevent seepage of leachate containing heavy metals into the subsoil and groundwater. It is well known that soil has the capability to physically and chemically retard the movement of contaminants (Calace et al. 2001; Rubinos \& Spagnoli 2019; Yanful et al. 1988; Zarime \& Wan Yaacob 2016). Soil can be compacted to achieve very low hydraulic conductivity of less than $1 \times 10^{-9} \mathrm{~m} / \mathrm{s}$ and acts as a final protection for groundwater against pollutants underneath the landfill sites. The most suitable types of soils are those which possess high cation exchange capacity (CEC), large specific surface area (SSA) and high chemical buffering capacity (Bohác et al. 2019; Yong et al. 1992). Soils are effective agents for metal sorption because of their high surface area and the presence of various surface functional groups (Davis 1984; Tessier et al. 1985). The compatibility of clay liner to a specific contaminant depends on two factors; the ability of the clay in the liner to resist increases in hydraulic conductivity caused by the contaminants and its capacity to retard the migration of contaminants through sorption (Li \& Li 2001).

Soil is a product of accumulation of different active components such as clay minerals, organic matters, carbonate fractions and oxy/hydroxides amorphous 
materials. These components are chemically reactive and can react with various types of contaminants resulting into the retention of contaminants in the soil system. Competency assessment of soil to be used as compacted clay liner is very important and can be investigated using soil column experiment. According to Yong et al. (1992), soil column experiment can provide information concerning the capability of natural soil to function as proper clay liner.

The study of interaction and behaviour of heavy metals in soils has been extensively studied during the past 20 years. Most of the studies involved the sorption assessment of heavy metals onto soils (Wan Zuhairi 2003a, 2003b; Wan Zuhairi et al. 2004), migration of heavy metals through clay (Antoniadis et al. 2007; Griffin et al. 1976; Yong \& Phadungchewit 1993; Yong et al. 2001) and partitioning of heavy metals from active soil components (Gupta \& Chen 1975; Rendina \& de lorio 2012; Tessier et al. 1979). Heavy metals were used in this study because they possess a very serious threat not only to the environment but also to human health due to their toxicity, persistence and nondegradability (Chotpantarat et al. 2011).

The objectives of the study were to assess the capability of three natural soils to function as engineered clay liner in landfill; to evaluate the long-term performance of compacted clay when it is exposed to aggressive chemicals of leachate in landfills; to investigate the retention/ migration profiles of heavy metals through the soil column.

\section{MATERIALS AND METHODS}

\section{PHYSICAL CHEMICAL EXPERIMENTS}

Fifteen samples from three different type of soils, namely Sungai Besar marine clay (SBMC1-5), weathered metasediments from Batang Berjuntai (HMS1-5) and river alluvium from Ampar Tenang (ARA1-5) were collected from different part of Selangor (Figure 1; Table 1). Sungai Besar marine clay is a quaternary deposit, consists predominantly of clay that is located near the costal and offshore (marine origin). Meanwhile, metasediment soil is a weathering product of metamorphic rocks. River alluvium soil is a product of sediments deposition by water along the river banks. All samples were subjected to physical and chemical tests. Physical tests comprised of particle size distribution, Atterberg Limits, compaction, specific gravity and permeability (falling head test). All tests follow the standard methods of British Standard (BS1377 1990). Chemical tests consisted of soil water pH (1:10 ratio), organic matter (Hesse 1972), carbonate contents (Hesse 1972), amorphous oxides/hydroxides (Segalen 1968), specific surface area (SSA) and cation exchange capacity (CEC) followed the method by McGill University Geotechnical Research Centre Laboratory Manual (Geotechnical Research Centre Laboratory Manual 1985). The clay mineralogy of the soil was determined using X-Ray Diffraction analysis.

\section{COLUMN EXPERIMENTS}

Soil column was utilized in this study to investigate the migration characteristics of heavy metals when passing through the compacted soil column. The column method is better to simulate natural soil conditions (Abollino et al. 2003; Sahu et al. 2012). Column experiment was designed to stimulate slow, saturated, anaerobic flow of leachate through the clay materials (Yong et al. 1992). This new physical model was redesigned and rebuilt based on previous model from Wan Zuhairi (2000) and Yong (2001) to reduce leakage especially along the joint/

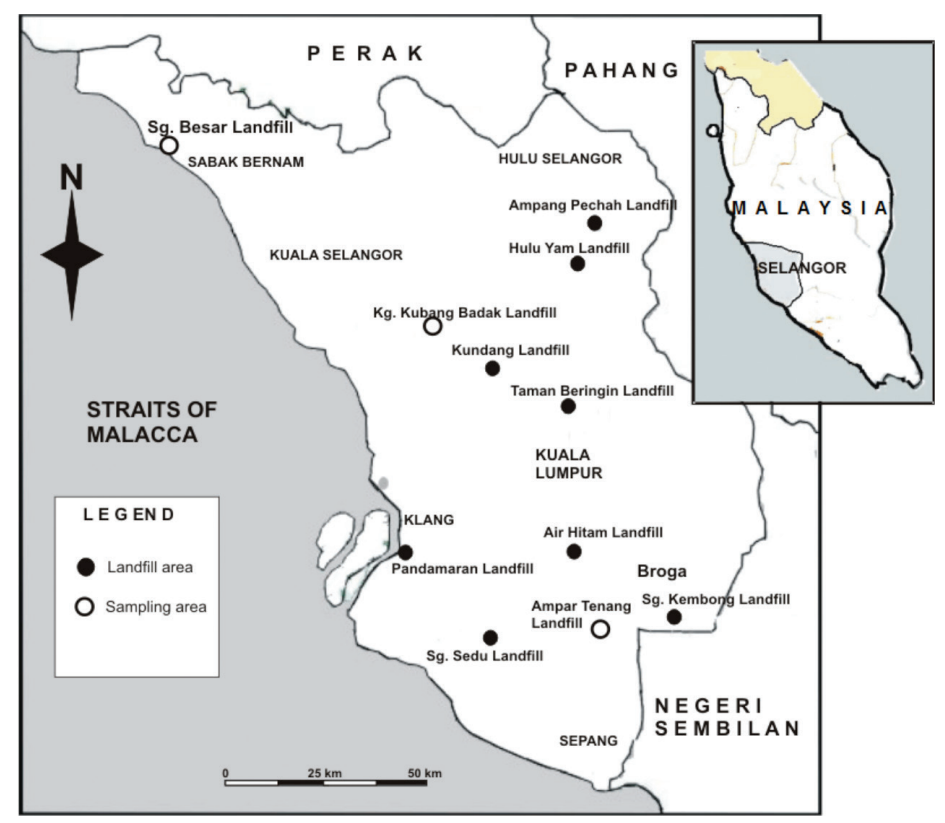

FIGURE 1. The sampling locations of three different soil in Selangor, Malaysia 
TABLE 1. Soil designations

\begin{tabular}{lll}
\hline Group & Samples & Description \\
\hline SBMC & SBMC1-SBMC5 & Marine clay (Silty clay) \\
HMS & HMS1-HMS5 & Weathered metasediments (Clayey silt) \\
ARA & ARA1-ARA5 & River alluvium (Clayey silt) \\
\hline
\end{tabular}

contact of different column components after they were attached together. This rather new soil column consisted of plexiglass cylinder with a diameter of $100 \mathrm{~mm}$ and length of $104 \mathrm{~mm}$. Column apparatus is comprised of two parts; top part is a leachate reservoir and the bottom part is a place for compacted soil (Figure 2). Glass microfiber filters (Whatmann) were placed on the porous disc at the top and bottom ends of the columns to prevent influx and outflux of particles. Each sample was tested in a series of duplicate with a label of $3 \mathrm{PV}$ and $5 \mathrm{PV}$, where $\mathrm{PV}$ represents the pore volume of soil. A pore volume (PV) is defined as the volume necessary to displace the volume of interstitial liquid in the pore spaces within the soil column. Soils at their optimum moisture content $\left(\mathrm{W}_{\mathrm{opt}}\right)$ were compacted into three separate layers in the plexiglass cylinder according to a Standard Proctor compaction test using $25 \mathrm{~kg}$ weight hammer. All components were attached together and screwed tightly to prevent leakage.

There were two stages of leaching for column test: saturation stage using deionized distilled water; and leaching stage using a test solution (i.e. spiked leachate) that was prepared by dissolving exact amount of salt nitrates. The leaching experiments were conducted under constant air pressure of 10 psi (i.e. equivalent to hydraulic gradient, $\mathrm{i} \sim 68$ ) to reduce the time factor for test solution transport through the soil columns. The chemical composition of spiked test solution is given by Table 2. The use of spiking is to increase the contaminant concentrations and is very useful to study more extreme conditions of contaminant attack to soil, i.e. a procedure that maximize the contaminant-soil interaction. The $\mathrm{pH}$ of the leachate was also reduced to 1.4 to increase the mobility of the heavy metals and to prevent any accumulation of the heavy metals in the reservoir (i.e. heavy metals are precipitated when $\mathrm{pH}>5.5$ ). After every $0.5 \mathrm{PV}$ of leaching, the effluents were collected and analysed using ICPMS. All effluents were filtered using Whatmann cellulose nitrate filter papers $(<0.2 \mu \mathrm{m}$ pore with $47-\mathrm{mm}$ diameter $)$ prior to analysis to prevent blockage of ICPMS tubing system. The $\mathrm{pH}$ of the effluents was measured using $\mathrm{pH}$ meter subsequently after $0.5 \mathrm{PV}$.

TABLE 2. The composition of test solution

\begin{tabular}{lc}
\hline Parameter & Value \\
\hline $\mathrm{Pb}$ & 538.6 \\
$\mathrm{Cu}$ & 556.8 \\
$\mathrm{Zn}$ & 516.8 \\
$\mathrm{Ni}$ & 567.9 \\
$\mathrm{pH}$ & 1.4 \\
Conductivity & $5.93 \mathrm{mS} / \mathrm{cm}$ \\
\hline
\end{tabular}

All concentration in $\mathrm{mg} / \mathrm{L}$ except for $\mathrm{pH}$ and conductivity

Column Tests
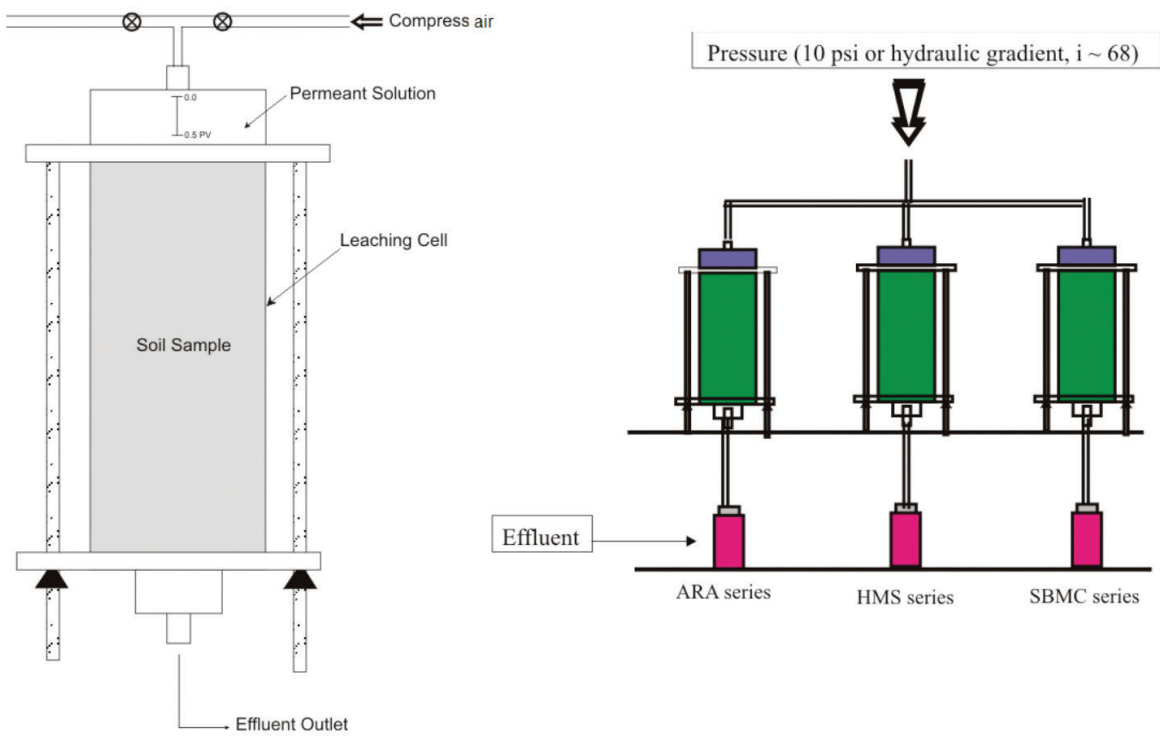

FIGURE 2. The schematic diagram of column experiment on three different soils 
At the end of the experiments (i.e. after permeated with test solution for up to $3 \mathrm{PV}$ and $5 \mathrm{PV}$, respectively), the compacted soils were extruded and sliced into six equal slices for soil analysis. Each slice measuring about $17 \mathrm{~mm}$ thick and digested using microwave digestion technique to determine the amount of heavy metals retained in the soil. Microwave digestion is a new instrument that uses microwaves and acids to digest the soil materials.

\section{RESULTS AND DISCUSSION}

\section{THE PROPERTIES OF SOILS}

Soils were characterized in terms of their physical and chemical constituents using standard procedures as mentioned in methods. These properties are very important and greatly influenced the suitability of the soil to function as engineered clay liner material. The physical-chemical data were also used as input data for setting up the physical column.

Soils have different capacity to adsorb heavy metals and are largely controlled by their physicochemical properties (Wan Zuhairi 2003a, 2003b, 2001, 2000; Wan Zuhairi et al. 2004). Wan Zuhairi and Abdul Rahim (2012) also showed that different soils have different sorption capacity for different heavy metals. The retardation factor (Kd values) are proportional to the sorption capacity of the soils. The relatively low hydraulic conductivity and high adsorption capacity of clay soils make them prime candidates for constructed or engineered clay barrier (Yong et al. 1993). The physical properties of the soils are important in relation to their capability to be compacted to achieve a minimum requirement of hydraulic conductivity of $1 \times 10^{-9} \mathrm{~m} / \mathrm{s}$ such as a requirement made by DOE (1995). On the other hand, the chemical characteristics of the clay materials are also very important to assess the capability of the soil to attenuate the contaminants. Tables 3 and 4 show the physical and chemical properties of all soils used in this study. The specific gravity values for all soils were found to be very similar and did not show much variation between soils, being in the range of 2.2 and 2.7. Soil HMS and ARA contained high percentage of sand with the values ranged from $11 \%$ to $45 \%$. Note that SBMC soil contained higher composition of fine fractions (i.e. 46-60\% and $33-52 \%$ for silt and clay, respectively). High clay content in SBMC gives a very good advantage for landfill liner material because clay can increase the sorption capability and reduce the hydraulic conductivity values of the soil. The average hydraulic conductivity values for SBMC soils were one order of magnitude lower than HMS and two orders of magnitude lower than ARA. This difference is due to high percentage (amount) of fine fractions in SBMC soil. SBMC and HMS soils were classified according to Unified Soil Classification System (USCS) as clay with high plasticity $(\mathrm{CH})$, while soil ARA was classified as silt with low plasticity (ML). This classification was made based on the particle size distribution and soil Atterberg limits values (i.e. LL, PL, and PI). Even though SBMC and HMS were classified as the same type of soil, their other chemical and physical properties were different.

The chemical parameters for all soils are presented in Table 4. The $\mathrm{pH}$ values for all soils were varied; ARA soils were acidic, ranged between 4.2 and 4.5 . $\mathrm{pH}$ values for SBMC soils were alkaline, in the range of 7.2 to 7.5. The $\mathrm{pH}$ readings for HMS were intermediate - values between 6.2 and 7.4. SBMC soils contained slightly higher organic and carbonate compared to HMS and ARA soils. Interesting to note the CEC and SSA values for SBMC were far beyond other soils, with the values of 25-75 meq/100 $\mathrm{g}$ for CEC and 90- $138 \mathrm{~m}^{2} / \mathrm{g}$ for SSA. Chalermyanont et al. (2009) stated the marine clay in Thailand had the value of $26.05 \mathrm{meq} / 100 \mathrm{~g}$ and this higher CEC indicates a higher negative charge of the clay fraction and hence, a higher heavy metal sorption capacity.

The major difference in soil chemical properties between SBMC and HMS/ARA soils was due to high amount

TABLE 3. Physical properties of three soils from Selangor, Malaysia

\begin{tabular}{lccccccccccc}
\hline Soils & Gs & S (\%) & M (\%) & C (\%) & LL (\%) & PL (\%) & PI (\%) & $\mathrm{W}_{\text {opt }}$ & $\gamma_{\text {dmax }}$ & K $\left(\times 10^{-9}\right) \mathrm{m} / \mathrm{s}$ & Class \\
\hline SBMC & $2.2-2.3$ & $2-8$ & $46-60$ & $33-52$ & $50-68$ & $18-28$ & $27-45$ & 29.32 & $1.4-1.4$ & 7.9 & $\mathrm{CH}$ \\
HMS & $2.4-2.7$ & $11-15$ & $45-56$ & $20-30$ & $39-57$ & $21-27$ & $14-35$ & $21-30$ & $1.3-1.5$ & 23.8 & $\mathrm{CH}$ \\
ARA & $2.2-2.4$ & $2-45$ & $42-71$ & $10-27$ & $39-50$ & $24-32$ & $11-25$ & $10-22$ & $1.5-1.6$ & 513 & $\mathrm{ML}$ \\
\hline
\end{tabular}

$\mathrm{Gs}=$ Specific gravity; LL=liquid limit; PI=plasticity index; $\mathrm{S}=\mathrm{Sand}$; $\mathrm{M}=\mathrm{Silts} ; \mathrm{C}=\mathrm{Clay} ; \gamma_{\mathrm{dmax}}=$ Maximum dry density; $\mathrm{W}_{\mathrm{opt}}=\mathrm{Optimum}$ moisture content; $\mathrm{K}=\mathrm{Hydraulic}$ conductivity; $\mathrm{CH}=$ clay with high plasticity; $\mathrm{CL}=$ clay with low plasticity; $\mathrm{ML}=$ silt with low plasticity

TABLE 4. Chemical properties of three soils from Selangor, Malaysia

\begin{tabular}{lcccccc}
\hline Soils & $\mathrm{pH}$ & Organic $(\%)$ & Carbonate $(\%)$ & CEC $(\mathrm{meq} / 100 \mathrm{~g})$ & $\mathrm{SSA}\left(\mathrm{m}^{2} / \mathrm{g}\right)$ & Mineralogy \\
\hline SBMC & $7.2-7.5$ & $5-14$ & $9-13$ & $25-75$ & $90-138$ & $\mathrm{M}>\mathrm{I}$ \\
HMS & $6.2-7.4$ & $3-13$ & $8-13$ & $1-6$ & $20-36$ & $\mathrm{~K}>\mathrm{I}$ \\
ARA & $4.2-4.5$ & $3-11$ & $4-15$ & $1-9$ & $12-16$ & $\mathrm{I}$ \\
\hline
\end{tabular}

SSA = specific surface area, $\mathrm{CEC}=$ cation exchange capacity $\mathrm{K}=$ Kaolinite $\mathrm{I}=\mathrm{Illite} ; \mathrm{M}=$ Montmorillonite; $\mathrm{SBMC}=\mathrm{Marine}$ clay from Sg Besar; $\mathrm{ARA}=\mathrm{River}$ alluvium soils from Ampar Tenang; and weathered metasediments of Batang Berjuntai (HMS) 
of clay fractions and the presence of active clay mineral (i.e. montmorillonite) in SBMC soils (Tables 3 and 4). Montmorillonite is an active clay mineral that increased the CEC and SSA values in SBMC soils. In other soils (HMS and ARA), montmorillonite is absent and mainly contain kaolinite and illite, resulting small values of SSA and CEC. Montmorillonite has higher SSA with the values range from $600-800 \mathrm{~m}^{2} / \mathrm{g}$ and CEC of $80-100 \mathrm{meq} / 100 \mathrm{~g}$ values compared with kaolinite/illite (SSA 5-20 m²/g and CEC 3-15 meq/100 g) (William 1997). Montmorillonite has a better potential for liner because of highest attenuation capability (Griffin \& Shimp 1978) and lower permeability (CIRIA 1996) compared to illite and kaolinite. Musso et al. (2014) stated that the total amount of metal sorption is strongly influenced by the total specific surface area, the presence of carbonates and the content of the clays in soil.

Based on the physical and chemical properties of the soils, one may conclude that the adsorption capability and the hydraulic conductivities of these materials were different, resulting in a difference in the rate of heavy metals movement in soils (Lo \& Liljestrand 1996). Soil SBMC has a better potential for liner material compared to ARA and HMS.

\section{THE BREAKTHROUGH CURVES OF HEAVY METALS THROUGH SOIL COLUMN}

The column experimental results are presented as breakthrough curves (BTCs) which were plotted between relative concentration $\left(\mathrm{C}_{\mathrm{e}} / \mathrm{C}_{\mathrm{o}}\right)$ against the pore volumes $(\mathrm{PV})$. Relative concentration $\left(\mathrm{C}_{\mathrm{e}} / \mathrm{C}_{\mathrm{o}}\right)$ is a ratio between concentration of heavy metals in the effluents and concentration of heavy metals in the influent. The relative concentration equals 1.0 represents the total breakthrough of heavy metals through the compacted soil column.

Figure 3(a) and Figure 3(b) shows the BTCs of Pb, $\mathrm{Cu}, \mathrm{Ni}$ and $\mathrm{Zn}$ for SBMC soil as observed in both PV3 and PV5 soil columns. It can be seen that $\mathrm{C}_{\mathrm{e}} / \mathrm{C}_{\mathrm{o}}$ values increased with the increasing numbers of pore volumes. The plots also showed that $\mathrm{Ni}$ and $\mathrm{Zn}$ were the most mobile heavy metals, with the $\mathrm{C}_{\mathrm{e}} / \mathrm{C}_{\mathrm{o}}$ after $3 \mathrm{PV}$ and $5 \mathrm{PV}$ were 0.006 and 0.6 , respectively. Low $\mathrm{C}_{\mathrm{e}} / \mathrm{C}_{\mathrm{o}}$ values (i.e. BTCs $<1.0)$ indicates that sorption of heavy metals was high in both soil colums. The curves in both columns also indicated that different heavy metals have different affinity (or selectivity) for sorption, where the affinity of heavy metals sorption can be ranked as $\mathrm{Pb}>\mathrm{Cu}>\mathrm{Ni} \approx \mathrm{Zn}$. The selectivity order is assumed to be inversely proportional to the hydrated radius of the metal with a smaller radius being more favourable for sorption (Chotpantarat et al. 2011). Pb has highest affinity for sorption compared to other metals, and according to Chotpantarat et al. (2011), the retention (sorption) of $\mathrm{Pb}$ was mainly regulated by the formation of strong covalent bonds as well as the possibility of formation of salts of metal. $\mathrm{Zn}$ and Ni were the least metal sorbed, as a consequence, they were more mobile and would move far in the soil.
The sorption of heavy metals in soil column in Figure 3(a) and Figure 3(b) also corresponded very well with the buffering capacity of the soil as indicated by the $\mathrm{pH}$ lines in both columns. The $\mathrm{pH}$ lines were almost constant from the start to end, with the values ranged from 7-8 for PV3 and $6.5-8$ for $\mathrm{PV} 5$. The $\mathrm{pH}$ of the test solution used in this experiment was 1.4. The $\mathrm{pH}$ profile indicated that SBMC soil has a very good buffering capacity, i.e soil has good capacity to resist any changes from an acidic test solution to maintain its $\mathrm{pH}$ from start to the end of the test. A number of adsorption studies indicate that within the $\mathrm{pH}$ range of soils (4 to 11), heavy metals adsorption increases with increasing pH (Bittel \& Miller 1974; Griffin \& Shimp 1976; Scrudato \& Estes 1975; Yang et al. 2012). High pH of soils increases the amount of heay metals sorbed due to the formation of heavy metals carbonate precipitates which is observed when the solution $\mathrm{pH}$ values exceeded 5 or 6 (Griffin \& Shimp 1976). Yang et al. (2012) also stated that chemical precipitation is considered as the dominant mechanism at $\mathrm{pH}>9$.

Figure 3(c) and Figure 3(d) shows the breakthrough curves of HMS soil after 3PV and 5PV of column leaching tests. The $\mathrm{C}_{\mathrm{e}} / \mathrm{C}_{\mathrm{o}}$ values were below the total breakthrough value (1.0), although Ni showed higher mobility (less sorption) in both 3PV and 5PV soil columns with the values of 0.7 and 0.8 , respectively. Further leaching will definitely resulting total breaktrough for $\mathrm{Ni}$ in column $\mathrm{PV} 3$, but interesting to note in column PV5, after 3 pore volumes of leaching, Ni breakthrough was slowly decreased (25\% decreasing from $\mathrm{C}_{\mathrm{e}} / \mathrm{C}_{\mathrm{o}}=0.8$ to $\mathrm{C}_{\mathrm{e}} / \mathrm{C}_{\mathrm{o}}=0.6$ ). This could not be justified whether Ni curves in column PV3 will follow the trend as shown by column PV5. Other heavy metals were highly retained in both columns. It is interesting to note that the mobility of $\mathrm{Pb}$ in both column $\mathrm{s}$ was quite high as compared to $\mathrm{Pb}$ in SBMC soil columns. However, the $\mathrm{C}_{\mathrm{e}} / \mathrm{C}_{\mathrm{o}}$ values were small, i.e. less than 0.3 . The affinity for sorption in these two columns can be ranked as $\mathrm{Zn} \approx$ $\mathrm{Cu}>\mathrm{Pb}>\mathrm{Ni}$. This new affinity order for sorption in HMS is so much different as shown earlier by SBMC soil (Figure 3(a) and Figure 3(b); probably due to different physical and chemical properties of these two soils. The $\mathrm{pH}$ lines also showed a drastic plunging in both HMS soil columns with an early $\mathrm{pH}$ values was 7.0 to a final $\mathrm{pH}$ values of 5.0 in both HMS columns. Based on the $\mathrm{pH}$ lines behaviour, one may conclude that HMS soils possess low buffering capacity, and this was an explanation to the behaviour pattern for $\mathrm{Ni}$ in both columns (i.e. poor buffering will increase the mobility of heavy metals and decreasing the ability for sorption in soils). Musso et al. (2014) stated that adsorption of heavy metals on soil surfaces can be considered as an evidence of clay-metal electrostatic interaction.

Figure 4(a) and Figure 4(b) shows the BTCs for ARA soils. The $\mathrm{C}_{\mathrm{e}} / \mathrm{C}_{\mathrm{o}}$ values for PV3 and PV5 soil columns were below 0.2 and 0.14 , respectively. Ni showed highest mobility in both columns, similar to that observed earlier in soil HMS. $\mathrm{Zn}$ and $\mathrm{Cu}$ showed the least mobile of HMs in both columns. The affinity for sorption in these two columns 


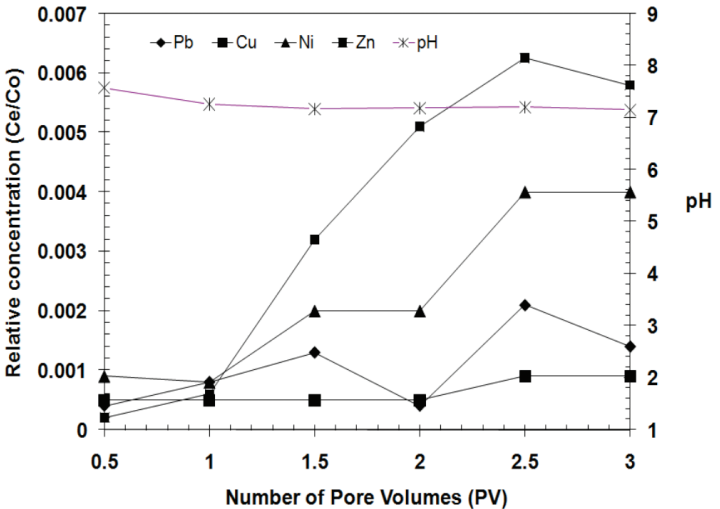

(a)

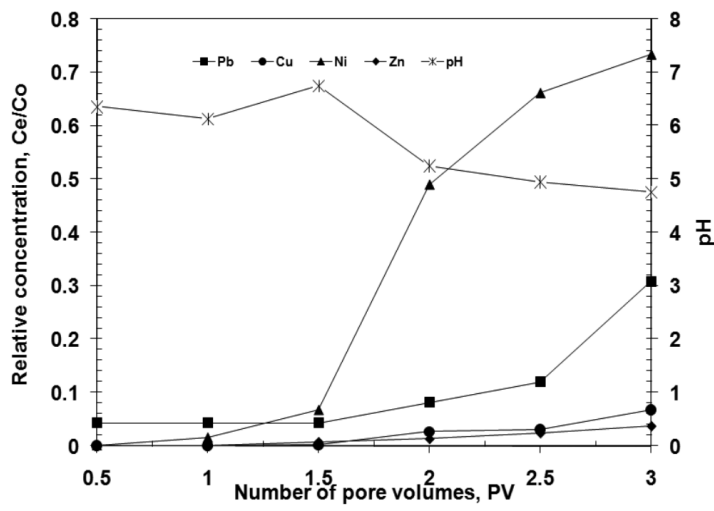

(c)

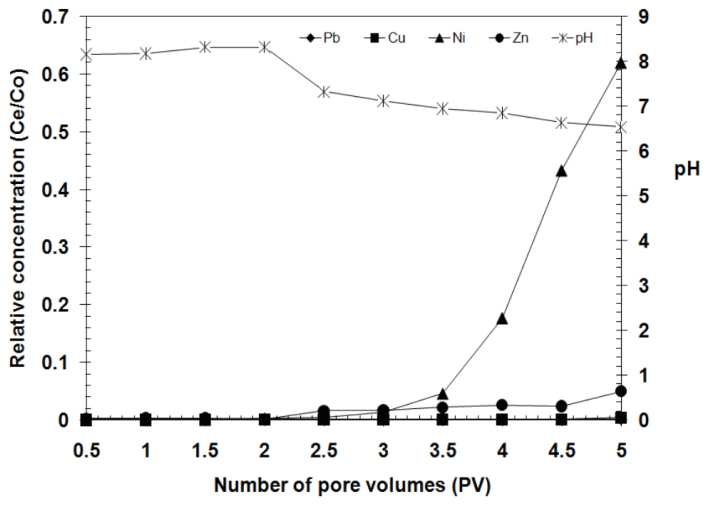

(b)

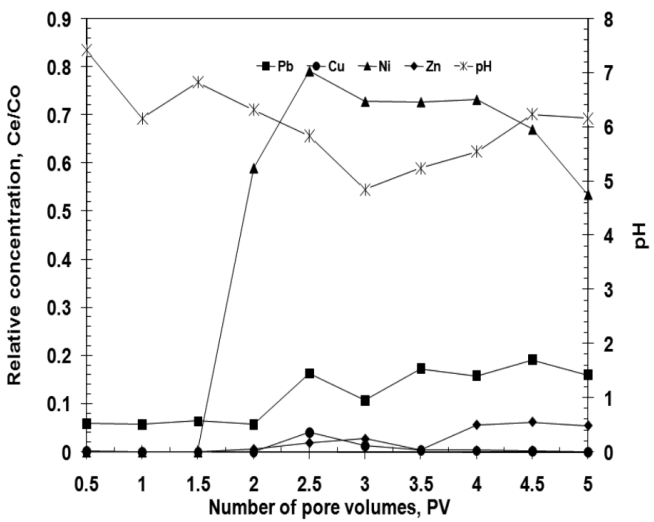

(d)

FIGURE 3. The breakthrough curves for (a) SBMC-3PV; (b) SBMC-5PV; (c) HMS-3PV and (d) HMS-5PV

can be ranked as $\mathrm{Zn} \approx \mathrm{Cu}>\mathrm{Pb}>\mathrm{Ni}$; which is similar as previously observed in HMS soil columns. ARA soil columns showed the lowest buffering capacity as shown by the $\mathrm{pH}$ lines. The $\mathrm{pH}$ decreased from the value of 5 to 4 after three pore volumes of leaching. However, the $\mathrm{pH}$ values were quite constant (pH4.0) in another soil column (5PV). The $\mathrm{pH}$ values shown in both columns were in an acidic region and may well indicate the poor buffering capacity of this soil. Figure 5(a) shows the $\mathrm{pH}$ lines of three compacted soils after $5 \mathrm{PV}$ of leaching. It was observed that after $5 \mathrm{PV}$ of leaching using $\mathrm{pH} \sim 1.4$ test solution, soil SBMC showed very high resistance to an acidic test solution, where the $\mathrm{pH}$ values throughout the test were in an alkaline region with the values of $\mathrm{pH} 8$ to 7 . This undoubtedly shows that soil SBMC has a very good buffering capacity and capable to buffer an acidic solution that act upon it. Since the $\mathrm{pH}$ values for the effluents showed a range of 6 to 8, one may conclude that all the heavy metals were precipitated in the soil columns. The amount of heavy metal ions $(\mathrm{Cu}, \mathrm{Zn}$, $\mathrm{Cd}, \mathrm{Pb}$ ) adsorbed by clay in acid media increases with increasing $\mathrm{pH}$, and it has been proposed that this effect is due to decreased competition from protons for adsorption sites. Beyond a threshold $\mathrm{pH}$ (e.g. $\mathrm{pH}>6$ for $\mathrm{Pb}, \mathrm{pH}>$ 7 for $\mathrm{Cd}$ ) virtually all the metal ion is removed from the aqueous phase, presumably as hydroxy species adsorbed on the surface of the suspended solid particles (Farrah \& Pickering 1977). Soils HMS and ARA were not good enough to buffer the acidic test solution. The $\mathrm{pH}$ values for HMS were in an alkaline region (pH7.5) at the start of the test ( $\sim \mathrm{PV} 1)$ but the $\mathrm{pH}$ decreased to an acidic region with further addition of test solution (final $\mathrm{pH}$ measured was 6.0). The worst soil to buffer an acidic test solution was shown by soil ARA, where the $\mathrm{pH}$ values were in an acidic region from start to the end of testing (final $\mathrm{pH} 4.0$ ). This demonstrated that soil ARA could not resist an acidic attack that was applied to it by an acidic test solution. In terms of soil buffering capacity of these soils, one can make a conclusion that soil SBMC has the highest buffering capacity then followed by soil HMS and ARA. The buffering capacity of these three soils can be ranked as SBMC $>$ HMS $>$ ARA.

The buffering capacity parameter plays very important role in the retention of heavy metals (Wan Zuhairi 2003). Soil with high buffering capacity retains most of the heavy metals as compared to soil with lowest buffering capacity. Soil SBMC had a capacity to retain all heavy metals in the test solution as given by Figure 5(b) (only $\mathrm{Pb}$ is shown here). Soils ARA and HMS had a lower retention capacity which were given by high values of $\mathrm{C}_{\mathrm{e}} / \mathrm{C}_{\mathrm{o}}$. However, the retention behaviors of ARA and HMS in Figure 5(b) was very confusing, as it was contradicted with the soils' buffering capacity (Figure 5(a)) and physical chemical properties (Tables 2 and 3). Based on the soils buffering capacity and soils physical chemical properties for HMS and ARA soils, soil HMS was better than soil ARA in terms 


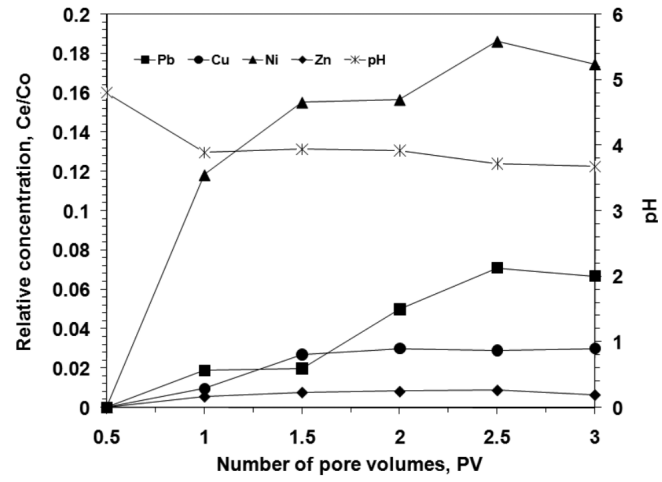

(a)

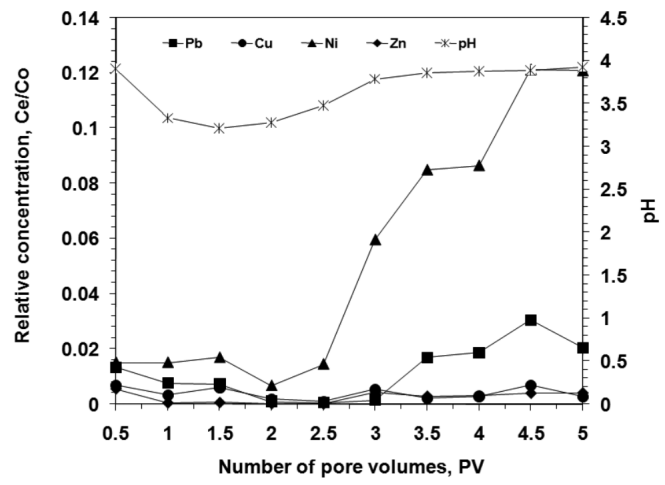

(b)

FIGURE 4. The breakthrough curves for (a) ARA-3PV and (b) ARA-5PV

of its capability to retain the heavy metals. However, the breakthrough curves in Figure 5(b) shows otherwise, whereby the retention of ARA was better than HMS. The reason for this behavior was probably due to the appearance of channel (micro fracture) in HMS soil column, resulting more heavy metals seeped through the compacted soil column. Further investigation is required to clarify this phenomenon. In terms of retention mechanism of heavy metals in compacted soil, there are a number of processes capable of attenuating leachate during its migration through natural materials. Four main mechanisms are identified consist of sorption/ion exchange, sorption by particulate organic matter, precipitation and dilution (Bright et al. 1996, Yong et al. 2001). These mechanisms are greatly controlled by the buffering capacity of the soil (i.e. resistance of soil against any changes to its $\mathrm{pH}$ ). Therefore, soil with high buffering capacity can predominantly retain the heavy metals via precipitation of soluble heavy metals into insoluble forms and stick to the soil solid particles. Meanwhile, soil with low buffering capacity will increase the mobility of heavy metals that can seep easily through the soil column. The uptake of heavy metal species by clay soil increases very significantly as the $\mathrm{pH}$ increased (Farrah \& Pickering 1976; Frost \& Griffin 1977).

\section{HEAVY METALS RETENTION PROFILES THROUGH COMPACTED SOIL COLUMN}

Figure 6(a), 6(b) and 6(c) shows the retention profiles of heavy metals from top to exit-end of the soil column after $5 \mathrm{PV}$ of leaching. The results were determined after an acid digestion technique of soil slices for each compacted soil. The retention profiles showed that most of the heavy metals were retained at the top $30 \mathrm{~mm}$ of the compacted soils. All figures also showed that $\mathrm{Pb}$ was predominantly retained at the top part of compacted soil (i.e. first $30 \mathrm{~mm}$ ) compared to other heavy metals. $\mathrm{Pb}$ retention profile in SBMC was high throughout the soil column, while $\mathrm{Zn}$ was the lowest metal retained in SBMC soil. This behavior is in agreement with BTCs shown previously in Figure 3(b), where $\mathrm{Zn}$ showed the highest mobility in this column (i.e. highest mobility means very small amount of $\mathrm{Zn}$ was retained in the soil column).

In the HMS compacted soil - Figure 6(b), Pb was the highest retained at the top $30 \mathrm{~mm}$ of the column $(0.029$ $\mathrm{mg} / \mathrm{g}$ ), but decreased very rapidly towards the end of the column $(0.003 \mathrm{mg} / \mathrm{g})$. Ni was observed to be very mobile in this soil, with the concentration of $\mathrm{Ni}$ in the soil was constant throughout the column, i.e. $0.002 \mathrm{mg} / \mathrm{g}$. It is also interesting to note that the retention profile for $\mathrm{Cu}$ increased

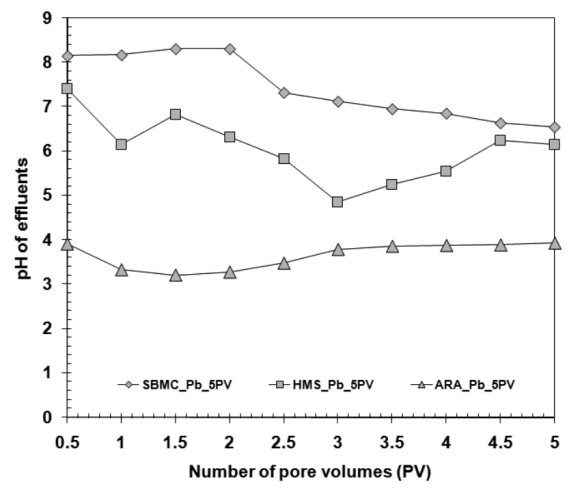

(a)

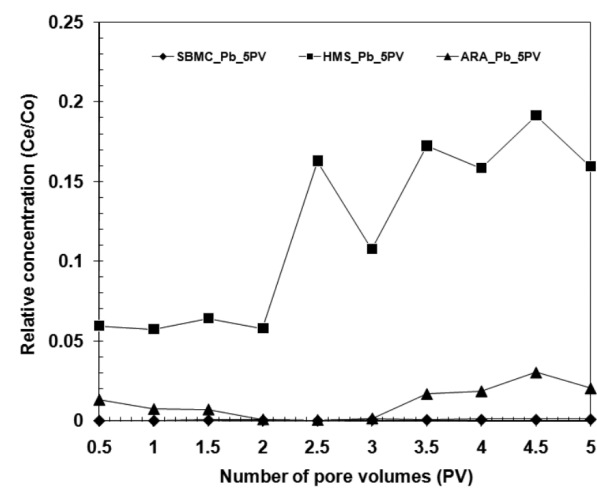

(b)

FIGURE 5. (a) The $\mathrm{pH}$ lines of three compacted soil columns SBMC, HMS and ARA, and (b) The comparison of $\mathrm{Pb}$ retention in three different soil columns SBMC, HMS and ARA 
below $30 \mathrm{~mm}$ and replaced $\mathrm{Pb}$ as the highest HM retained. Similar observation was discovered in ARA compacted soil, where $\mathrm{Pb}$ was the highest $\mathrm{HM}$ retained at the top $30 \mathrm{~mm}$ and then was replaced by $\mathrm{Cu}$ below $30 \mathrm{~mm}$ until at the exit-end of the column. However, $\mathrm{Zn}$ was the least HM retained in ARA soil resulting very small concentration of $\mathrm{Zn}$ being retained in this soil (with the average concentration of $0.003 \mathrm{mg} / \mathrm{g}$ ).

The $\mathrm{Pb}$ retention profiles in all compacted soils after $5 \mathrm{PV}$ of leaching are presented in Figure 6(d). It showed very clearly that SBMC had a capacity to retain high amount of $\mathrm{Pb}$ compared to ARA and HMS compacted soils. HMS only retained high concentration of $\mathrm{Pb}$ at the top $30 \mathrm{~mm}$ of the column, and below $30 \mathrm{~mm}$ the retention of $\mathrm{Pb}$ decreased very rapidly. The results in Figure 6(d) illustrated that SBMC was a good soil to retain heavy metals $(\mathrm{Pb})$ and followed by ARA and HMS soils. It was still puzzling why ARA showed better sorption for $\mathrm{Pb}$ as compared to HMS, as the physical and chemical properties (Tables 2 and 3 ) were in favor for HMS as a best material to retain heavy metals. However, this discrepancy between ARA and HMS was also discovered in the breakthrough curves of $\mathrm{Pb}$ in these soils - Figure 5(b). Recall back the physico-chemical properties of SBMC, most of the physical and chemical properties of SBMC were in-

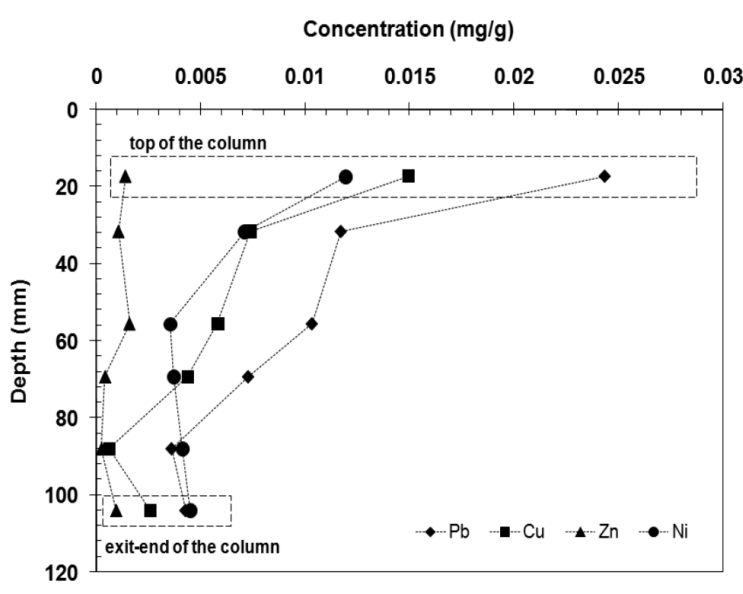

(a)

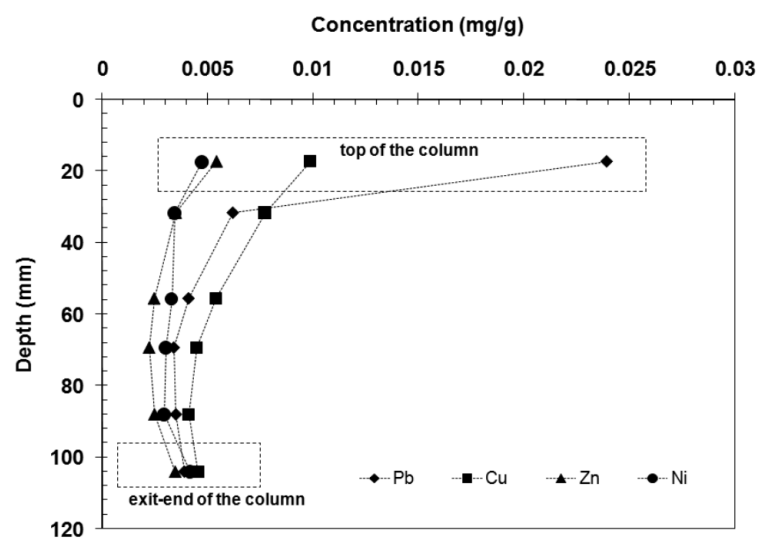

(c) favor for high sorption. CEC and SSA values for SBMC were higher compared to other soil materials due to active mineral montmorillonite. According to Chalermyanont et al. (2009), higher CEC indicates a higher negative charge of the soil and hence, a higher heavy metal sorption capacity. Finally, due to discrepancy in soil physico-chemical properties and different buffering capacity of these soils, hence, they have difference adsorption capability and different rate of heavy metals mobility.

The retention of heavy metals by these three different soils was greatly contributed by their clay contents. SBMC had higher amount of clay content with $33-52 \%$, followed by HMS and ARA with 2.2-2.7\%. As a result, SBMS showed higher sorption (retention) of heavy metals compared to other soils. Clay particles in soil increase the SSA and CEC values of the soils, hence increase the negatively charged of the soil and increase the sorption capability of the soil. The other factor that can contribute to higher sorption capability of the soil is the type of clay presents in the soil. SBMC soil had high percentage of clay fraction also contains active clay mineral montmorillonite. This active mineral increased the CEC, SSA and sorption values of the SBMC soil. According to Li et al. (2017), the column tests in their study showed

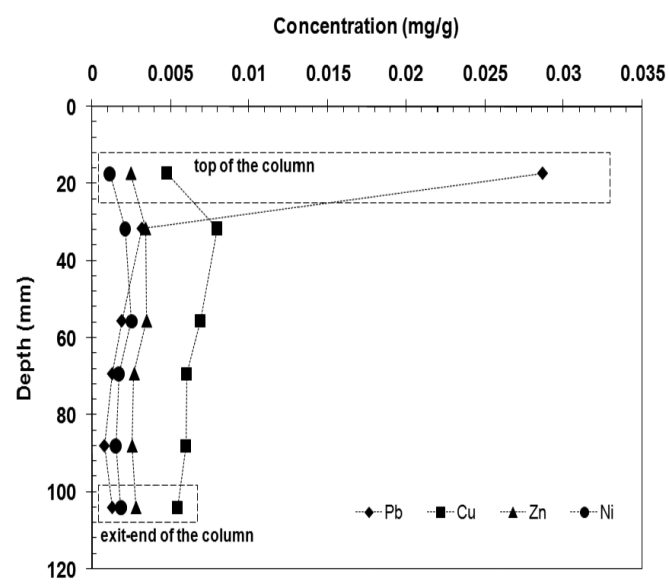

(b)

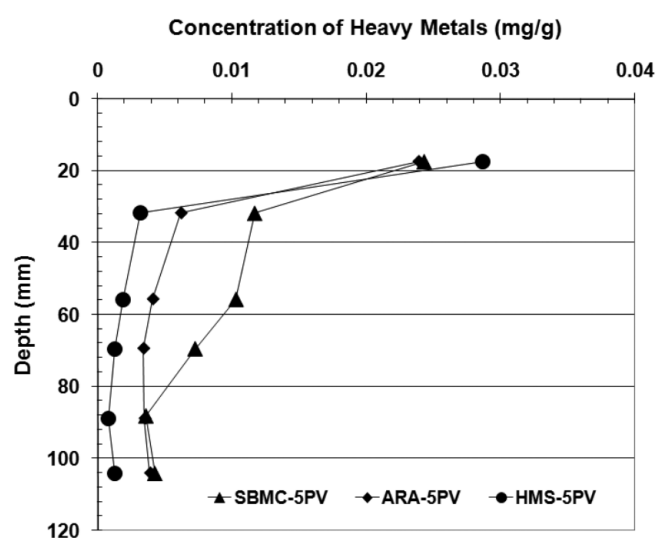

(d)

FIGURE 6. The retention profiles of (a) SBMC (b) HMS and (c) ARA after 5PV of leaching,

(d) retention profiles of $\mathrm{Pb}$ for soil columns SBMC, ARA and HMS 
that as the shale content increased, the retardation factors of $\mathrm{Zn}, \mathrm{Cd}, \mathrm{Pb}$, and $\mathrm{Cr}$ also increased.

\section{CONCLUSION}

This study has showed that soils have different capacity to retain heavy metals and very much depending on their physical and chemical properties. The affinity or selectivity of heavy metals for sorption (or retention) also varies in different types of soils, as been proven by the study. The study discovered that heavy metals entered the soil columns were retained predominantly at the top $30 \mathrm{~mm}$. Most of heavy metals were retained and only certain heavy metals species were allowed to migrate through the soil column. Soil SBMC has a capability to retain most of the heavy metals, and also has good buffering capacity to maintain its $\mathrm{pH}$ against an acidic solution ( $\mathrm{pH} 1.4)$, therefore increasing the chances of retaining most of heavy metals via natural attenuation (i.e. precipitation). Engineering application of these findings is that soil SBMC has a very good potential to function as liner material compared to two other soils (ARA and HMS) due to its low hydraulic conductivity and its high heavy metal attenuation capability.

\section{ACKNOWLEDGEMENTS}

This study is funded by the Ministry of Environment and Innovation (MOSTI), Malaysia through their research grant No. 06-01-02-SF0153.

\section{REFERENCES}

Abollino, O., Aceto, M., Malandrino, M., Sarzanini, C. \& Mentasti, E. 2003. Adsorption of heavy metals on Namontmorillonite. Effect of $\mathrm{pH}$ and organic substances. Water Research 37: 1619-1627.

Antoniadis, V., McKinley, J.D. \& Wan Zuhairi, W.Y. 2007. Singleelement and competitive metal mobility measured with column infiltration and batch test. Journal of Environmental Quality 32: 865-875.

Bittel, J.R. \& Miller, R.J. 1974. Lead, cadmium and calcium selectivity coefficients on montmorillonite, illite and kaolinite. Journal of Environmental Quality 3: 250-253.

Bohác, P., Delavernhe, L., Zervas, E., Königer, F., Schuhmann, R. \& Emmerich, K. 2019. Cation exchange capacity of bentonite in a saline environment. Applied Geochemistry 100 (October 2018): 407-413. https://doi.org/10.1016/j. apgeochem.2018.12.019.

Bright, M.I., Thornton, S.F., Lerner, D.N. \& Tellam, J.H. 1996. Laboratory investigations into designed high attenuation landfill liners. In Engineering Geology of Waste Disposal, Vol. 11, edited by Bentley, S.P. London: Geological Society Engineering Geology Special Publications. pp. 159-164.

British Standard Institution, BS1377. 1990. Method of Test for Soils for Civil Engineering Purposes.

Calace, N., Massimiani, A., Petronio, M. \& Pietroletti, M. 2001. Municipal landfill leachate - soil interactions: A kinetic approach. Chemosphere 44(5): 1025-1031.

Chalermyanont, T., Arrykul, S. \& Charoenthaisong, N. 2009. Potential use of lateritic and marine clay soils as landfill liners to retain heavy metals. Waste Management 29(1): 117-127.
Chotpantaratat, S., Ong, S.K., Sutthirat, C. \& Osathaphana, K. 2011. Competitive sorption and transport of $\mathrm{Pb}^{2+}, \mathrm{Ni}^{2+}, \mathrm{Mn}^{2+}$, and $\mathrm{Zn}^{2+}$ in lateritic soil columns. Journal of Hazardous Materials 190: 391-396.

CIRIA. 1996. Barriers, Liners and Cover Systems for Containment and Control of Land Contamination. Construction Industry Research and Information Association, Special Publication 124. London: Thomas Telford.

Davis, J.A. 1984. Complexation of trace metals by adsorbed natural organic matter. Geochimica et Cosmochimica Acta 48: 679-691.

Department of Environment (DOE). 1995. Landfill design, construction and operational practice. Waste Management Paper 26B, HMSO.

Farrah, H. \& Pickering, W.F. 1977. Influence of clay-solute interactions on aqueous heavy metal ion levels. Water, Air Soil Pollute 8: 189-197.

Farrah,H. \& Pickering, W.F. 1976. The sorption of zinc species by clay minerals. Australian Journal Chemical 29: 1649-1656.

Frost, R.R. \& Griffin, R.A. 1977. Effect of pH on adsorption of cooper, zinc and cadmium from landfill leachate by clay minerals. Journal of Environmental Science and Health 12(4\&5): 139-156

Geotechnical Research Centre Laboratory Manual. 1985. Laboratory Manual. Mc Gill University, Montreal Canada (unpublished).

Griffin, R.A. \& Shimp, N.F. 1978. Attenuation of Pollutants in Municipal Landfill Leachate by Clay Minerals. Report: EPA-600/2-78-157. U.S Environmental Protection Agency.

Griffin, R.A. \& Shimp, N.F. 1976. Effect of pH on the exchangeadsorption or precipitation of lead from landfill leachates by clay minerals. Environmental Science and Technology 10: $1256-1261$

Griffin, R.A., Shimp, N.F., Steele, J.D., Ruch, R.R., White, W.A. \& Hughes, G.M. 1976. Attenuation of pollutants in municipal landfill leachate by passage through clay. Environmental Science and Technology 10: 1262-1268.

Gupta, S.K. \& Chen, K.Y. 1975. Partitioning of trace metals in selective chemical fractions of near shore sediments. Environ. Lett. 10: 129-158.

Hesse, P.R. 1972. A Textbook of Soil Chemical Analysis. New York: Chemical Publishing Co. Inc.

Li, L.Y. \& Li, F. 2001. Heavy metal sorption and hydraulic conductivity studies using three types of bentonite admixes. Journal of Environmental Engineering 127(5): 20-429.

Li, L., Lin, C. \& Zhang, Z. 2017. Utilization of shale-clay mixtures as a landfill liner material to retain heavy metals. Materials \& Design 114: 73-82.

Lo, I.M. \& Liljestrand, H.M. 1996. Laboratory sorption and hydraulic conductivity tests: Evaluation of modified clay materials. Waste Management \& Research 14: 297-310. https://doi.org/10.1177/0734242X9601400305.

Musso, T.B., Parolo, M.E., Pettinari, G. \& Francisca, F.M. 2014. $\mathrm{Cu}(\mathrm{II})$ and $\mathrm{Zn}$ (II) adsorptio capacity of three different clay liner materials. Journal of Environmental Management 146: 50-58.

Rendina, A. \& de Iorio, A.F. 2012. Heavy metal partitioning in bottom sediments of the Matanza-Riachuelo River and Main Tributary streams. Soil \& Sediment Contamination 21(1): 62-81. DOI: 10.1080/15320383.2012.636776.

Rubinos, D.A. \& Spagnoli, G. 2019. Assessment of red mud as sorptive landfill liner for the retention of arsenic. Journal of Environmental Management 232: 271-285. 
Sahu, S., Nath, B., Roy, S., Mandal, B. \& Chatterjee, D. 2012. Bioavailability of arsenic in the soil horizon: A laboratory column study. Environ. Earth Sci. 65(3): 813-821.

Scrudato, R.J. \& Estes, E.L. 1975. Clay-lead sorption studies. Environmental Geology 1: 167-170.

Segalen, P. 1968. Note sur une methode de determination des produits mineraux amorphes dans certains sols a hydroxides tropicaux. Cah, Orstom Ser. Pedol. 6: 105-126.

Tessier, A., Rapin, F. \& Carignan, R. 1985. Trace metals in oxic lake sediments: Possible adsorption onto iron oxyhydroxides. Geochimica et Cosmochimica Acta 49: 183-194.

Tessier, A., Campbell, P.G.C. \& Bison, M. 1979. Sequential extraction procedure for the speciation of particulate trace metals. Anal. Chem. 51: 844-850.

Wan Zuhairi, W.Y. \& Abdul Rahim Samsudin. 2007. Sorption parameters of $\mathrm{Pb}$ and $\mathrm{Cu}$ on natural clay soils from Selangor, Malaysia. Sains Malaysiana 36(2): 149-157.

Wan Zuhairi, W.Y. 2003a. Heavy metal sorption capabilities of some soil samples from active landfill sites in Selangor. Geological Society of Malaysia Bulletin 46: 295-297.

Wan Zuhairi, W.Y. 2003b. Sorption capacity on lead, copper and zinc by clay soils from South Wales, United Kingdom. Journal of Environmental Geology 45(2): 236-242.

Wan Zuhairi, W.Y. 2001. Soils suitability for landfill liner material based on their physico-chemical properties: A case study from South Wales, United Kingdom. Majalah Geologi Indonesia (MGI - Special Edition ISSN 0216-1061) 16: 115-122.

Wan Zuhairi, W.Y. 2000. An investigation of natural attenuation characteristic of natural clay soils from South Wales and their potential use as engineered clay liner. PhD Thesis, Cardiff University (Unpublished).

Wan Zuhairi, W.Y., Abdul Rahim, S., Mohd Ramziemran \& Chan, Y.L. 2004. Natural sorption capability of heavy metals: Granitic residual soil from Broga and marine clay from Sg. Besar Selangor. Geological Society of Malaysia Bulletin 48: 13-16.

William, J.D. 1997. Groundwater Geochemistry: Fundamental and Application to Contamination. Boca Raton: Lewis Publisher.
Yanful, E.K., Quigley, R.M. \& Nesbitt, H.W. 1988. Heavy metal migration at a landfill site, Sarnia, Ontario, Canada-2: Metal partitioning and geotechnical implications. Applied Geochemistry 3: 623-629.

Yang, Q.L., Zhang, J.L., Yang, Q., Yu, Y.X. \& Yang, G. 2012. Behavior and mechanism of Cd(II) adsorption on loessmodified clay liner. Desalin. Water Treat 39(1-3): 10-20.

Yong, R.N., Yaacob, W.Z.W., Bentley, S.P., Harris, C. \& Tan, B.K.2001. Partitioning of heavy metals on soil samples from column tests. Engineering Geology 60: 307-322.

Yong, R.N. 2001. Contaminated Soils, Pollutant Fate and Mitigation. New York: CRC Press.

Yong, R.N. \& Phadungchewit, Y. 1993. pH influence on selectivity and retention of heavy metals in some clay soil. Canadian Geotechnical Journal 30: 821-833.

Yong, R.N., Galvez-Cloutier, R. \& Phadungchewit, Y. 1993. Selective sequential extraction analysis of heavy metal retention in soil. Canadian Geotechnical Journal 30: 834847.

Yong, R.N., Mohamed, A.M.O. \& Warkentin, B.P. 1992. Principles of Contaminant Transport in Soils. New York: Elsevier.

Zarime, N.A. \& Wan Yaacob, W.Z. 2016. The movement of cadmium (Cd) through compacted granitic residual soil using mini column infiltration technique. Sains Malaysiana 45(12): 1905-1912

Center for Earth Sciences and Environment Faculty of Science and Technology Universiti Kebangsaan Malaysia 43600 UKM Bangi, Selangor Darul Ehsan Malaysia

*Corresponding author; email: yaacobzw@ukm.edu.my

Received: 18 April 2019

Accepted: 15 August 2019 